\title{
NEUROG1 Gene
}

National Cancer Institute

\section{Source}

National Cancer Institute. NEUROG1 Gene. NCI Thesaurus. Code C105859.

This gene plays a role in both neuronal differentiation and transcriptional regulation. 